INFO ARTIKEL

Riwayat Artikel:

Diterima : 15 Juli 2020

Disetujui : 17 Agustus 2020

\title{
GEOGRAFI
}

\section{PENENTUAN ZONA KERENTANAN AIRTANAH METODE SIMPLE VERTICAL VULNERABILITY DI PULAU YEBEN}

\author{
Septian Vienastra ${ }^{1}$, Erik Febriart ${ }^{2}$, \\ ${ }^{1}$ Teknik Geologi, Fakultas Teknologi Mineral, Institut Sains dan Teknologi AKPRIND, Yogyakarta \\ ${ }^{2}$ Magister Pengelolaan Pesisir dan Daerah Aliran Sungai, Fakultas Geografi UGM, Yogyakarta \\ (区) *: vienastra@akprind.ac.id
}

\begin{abstract}
The potential for groundwater in the Raja Ampat Islands as a tourist destination is very limited, this is due to limited groundwater recharge and high utilization of groundwater. Excessive use of groundwater results in a decrease in the quantity and quality of groundwater. Decreasing groundwater quality can increase the vulnerability of groundwater to pollution. Groundwater vulnerability can be known intrinsically, by considering the physical properties of the rock. The purpose of this study was to determine the susceptibility class of groundwater to pollution in shallow aquifers by assessing the intrinsic vulnerability of the rock (geology). To obtain the results, the method used is the vulnerability assessment using the Simple Vertical Vulnerability $(S V V)$ method. This method uses simple rock effectiveness parameters or can be used in areas where there is not much information on hydrogeological conditions and application to shallow aquifers $<30 \mathrm{~m}$. The results showed that the zone of very high groundwater vulnerability (58.5\%) was found in the morphology of the coastal plains, high vulnerability (23.9\%) was in the transition from coastal plain to hilly morphology and moderate vulnerability (17.5\%) in hilly morphology. . The safe zone for groundwater utilization is in the high intrinsic vulnerability zone with the pumping treatment of no more than $0.8 \mathrm{~m}$ reduction. Excessive pumping can result in intrusion of sea water.
\end{abstract}

Keywords: Groundwater, Aquifer, Vulnerability, Geographic Information System

\begin{abstract}
Potensi airtanah di Kepulauan Raja Ampat sebagai tempat destinasi wisata sangat terbatas, hal tersebut disebabkan imbuhan airtanah yang terbatas dan tingginya pemanfaatan airtanah. Pemanfaatan airtanah secara berlebihan mengakibatkan penurunan kuantitas dan kualitas airtanah. Penurunan kualitas airtanah dapat menyebakan mengingkatnya kerentanan airtanah terhadap pencemaran. Kerentanan airtanah dapat diketahui secara intrinsik, dengan mempertimbangkan sifat fisik batuan. Tujuan dari penelitian ini adalah untuk mengetahui kelas kerentanan airtanah terhadap pencemaran pada akuifer dangkal dengan penilaian kerentanan secara intrinsik atau fisat fisik batuan (geologi). Untuk memperoleh hasil tersbut metode yang digunakan adalah penilaian kerentanan dengan metode Simple Vertical Vulnerability (SVV). Metode ini menggunakan parameter efektifitas batuan secara sederhana atau dapat digunakan pada kondisi pada daerah yang tidak banyak informasi kondisi hidrogeologi dan penerapan pada akuifer dangkal $<30 \mathrm{~m}$. Hasil penelitian menunjukkan bahwa zona kerawanan airtanah sangat tinggi $(58,5 \%)$ didapatkan pada morfologi dataran pantai, kerentanan tinggi $(23,9 \%)$ berada pada peralihan morfologi dataran pantai hingga ke perbukitan dan kerentanan sedang $(17,5 \%)$ pada morfologi perbukitan. Zona aman untuk pemanfaatan airtanah terdapat pada zona kerentanan intrinsik tinggi dengan perlakuan pemompaan tidak lebih dari penurunan $0,8 \mathrm{~m}$. Pemompaan berlebihandapat mengakibatkan intrusi airlaut.
\end{abstract}

Kata Kunci: airtanah, akuifer, kerentanan, sistem informasi geografis. 


\section{PENDAHULUAN}

Airtanah merupakan semua air yang terdapat dalam lapisan tanah atau batuan di bawah permukaan tanah pada zona jenuh air (BSN, 2005). Keterdapatan airtanah dipengaruhi oleh media simpanan air pada batuan berupa rongga antar butir maupun percelahan (Todd and Mays, 2005; Fetter, 2010). Batuan dengan ukuran butir yang semakin kasar mempunyai kemampuan menyimpan airtanah dan meloloskan airtanah dengan baik. Kemampuan akuifer dengan meloloskan atau mengalirkan airtanah yang tinggi mempengaruhi sifat potensi debit airtanah (Singhal dan Gupta, 2010).

Produktivitas airtanah yang tinggi, merupakan zona ideal dalam pemanfaatan airtanah. Hal tersebut dipengaruhi oleh faktor cekungan airtanah dengan ketebalan akuifer, dapat menympan airtanah dan melolosakan dengan debit yang besar (Fetter, 1999). Airtanah dengan produktivitas tinggi dipengaruhi oleh sifat media batuan atau litologi berupa rongga pasiran dengan rongga antar butir sedang hingga kasar, litologi akuifer tebal $>5 \mathrm{~m}$, terdapat bagian imbuhan air tanah (curah hujan tinggi) dan pelepasan air tanah yang berlangsung seimbang (Todd and Mays, 2005; Hendrayana dan Putra, 2008).

Keterdapatan air tanah pada luasan yang kecil seperti pulau kecil sangat tergantung oleh imbuhan atau curah hujan (Purnama, dkk, 2018; Febriarta dkk, 2018). Keterdapatan airtanah yang terbatas dapat menimbulkan penurunan kulitas airtanah yang dapat dipengaruhi oleh masuknya sumber pencemar kedalam airtanah (Febriarta dkk, 2020). Pemasalahan airtanah pada akuifer dengan kedalaman dangkal adalah kerentanan terhadap pencemaran (Fetter, 1999; Cahyadi, 2019). Kerentanan air tanah menjadi isu yang penting karena dapat merusak menurunkan kualitas airtanah, hingga dapat mnyebabkan permasalahan lingkungan yang berdampak pada penurunan kesehatan dalam mengkonsumsi airtanah. Kerentanan airtanah menyebabkan terbatasnya pemanfaatan sumberdaya air, terlebih pada kerentanan terhadap pencemaran, sehingga menurunkan kualitas airtanah, maka pemetaan kerentanan airtanah merupakan salah satu bentuk pengelolaan dan pemeliharaan sumber daya air (Fetter, 1999; Cahyadi, 2019; Putranto dkk, 2019).

Pulau Yeben merupakan pulau kecil dengan luas $572.402 \mathrm{~m}^{2}$ atau $0,57 \mathrm{~km}^{2}$ merupakan daerah destinasi wisata dengan penggunaan air tinggi yang berada di Kepuluan Raja Ampat Papua Barat. Pulau Yeben berada pada Formasi Yeben (Tmy) (Gambar 1) yang merupakan peralihan dari tersier menuju kuarter. Formasi tersbut tersusun oleh batupasir arkosa berselingan dengan napal kunning, tidak begitu kompak, banyak mengandung foraminifera kecil, diantaranya Globorotalia plesitumida BLOW dan BANNER, Globorotalia lenguaenisis BOLLI (Supriatna dkk, 1995). Terbentuk pada lingkungan pengendapan laut dangkal dan terbuka, dengan tebal lebih kurang 150m (Supriatna dkk, 1995; ESDM, 2017; Vienastra dan Febriarta, 2018).

Morfologi di Pulau Yeben terdiri atas perbukitan batupasir dan dataran pantai dengan penyusun batuan alluvial. Secara umum keterdapatan airtanah berada pada peralihan morfologi perbukitan pasir hingga ke dataran pantai. Penyusun dataran pantai tersusun atas pasiran sehingga tipe akuifer berupa pasiran lepaslepas (ESDM, 2017; Vienastra dan Febriarta, 2018; Febriarta dkk, 2020).

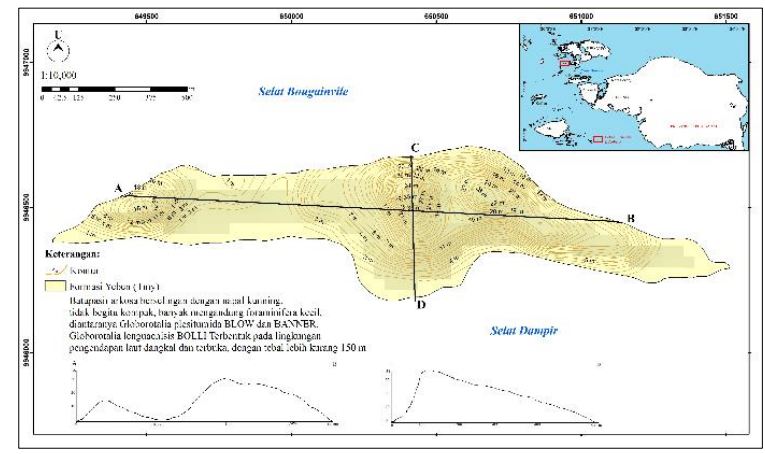

Gambar 1. Geologi regional

Karakteristik akiufer dengan media pasiran lepas-lepas mempunyai kerentanan pencemaran lebih tinggi, yang dipengaruhi oleh nilai kelulusan airtanah yang tinggi (Devianto dkk, 2019; Putranto dkk, 2019). Material penutup batuan dengan ukuran butir sedang hingga kasar mempunyai potensi mengalirkan sumber 
pencemar masuk kedalam sistem akuifer air tanah (Fetter, 1999; Hendrayana dan Putra, 2011; Putranto dkk, 2019). Pengelolaan airtanah dengan memperhatikan faktor kerentanan pencemaran merupakan salah satu upaya untuk menjaga keberlangsungan airtanah (Maria, 2017; Abuduwaili et all, 2019). Berdasarkan latar belakang tersebut, maka tujuan penelitian ini adalah untuk menentukan daerah atau zona kerentanan airtanah terhadap pencemaran pada akuifer pasiran.

\section{METODE PENELITIAN}

Pendekatan yang digunakan untuk mengetahui potensi kerentanan airtanah dangkal adalah dengan metode Simple Vertical Vulnerability (SVV) yang dikembangkan oleh Putra (Hendrayana dan Putra, 2008). Pendekatan Simple Vertical Vulnerability (SVV) merupakan pendekatan kerentanan dengan memberikan penlilaian terhadap hidrogeologi dangkal dengan rentang kedalaman airtanah tidak lebih dari $30 \mathrm{~m}$ pada batuan kuarter dan pada daerah dengan informasi data yang terbatas (Putra, dalam Hendrayana dan Putra, 2008).

Pendekatan kerentanan didasarkan atas sifat keefektifan batuan dalam menyimpan dan meloloskan airtanah dengan mempertimbangkan imbuhan airtanah yang masuk. Parameter yang digunakan untuk perhitungan indek kerentanan metode Simple Vertical Vulnerability (SVV) antara lain, Tipe material zona tak jenuh / lapisan penutup / overlaying material (La), ketebalan zona tidak jenuh air/ kedalaman muka airtanah $(Z)$ dan imbuhan airtanah / recharge / perkolasi (Wu) (Gambar 2). Dari setiap kelas dari paremeter tersebut dinilai berdasarkan mengacu nilai faktor untuk Simple Vertical Vulnerability (SVV).

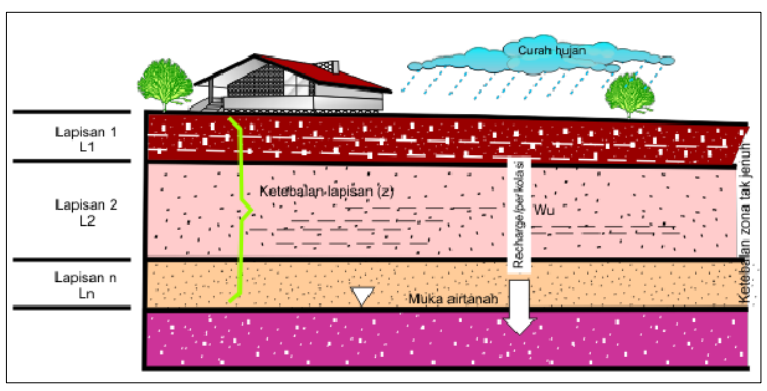

Gambar 2. Parameter dan evaluasi dari kerentanan airtanah metode SVV (Putra, 2007 dalam

Hendrayana dan Putra, 2008)

Nilai point faktor untuk material zona tak jenuh (La) disajikan pada Tabel 1. Nilai point faktor untuk ketebalan zona tidak jenuh / kedalaman muka air tanah (Z) diperoleh sesuai dengan poin yang sesuai dengan kedalaman muka airtanah (m). Nilai kelas kedalaman muka airtanah disajikan pada Tabel 2. Nilai point faktor untuk imbuhan airtanah/ rechargel perkolsi (Wu) disajikan pada Table 3.Untuk menghitung nilai point faktor untuk imbuhan airtanah/ rechargel perkolsi (Wu) dapat dihitung dengan pendekatan rumus (Putra, 2007 dalam Hendrayana, 2011), sebagai berikut:

Recharge $=$ curah hujan-evapotranspirasi nyata - runoff ....

Nilai evapapotranspirasi nyata dapat diperoleh dengan perhitungan dengan pendekatan rumus (Turc, 1964, dalam Hendrayana, 2011)

$$
E T r=\frac{P}{\sqrt{0,9+\frac{p 2}{\left(300+25 T+0,05 T^{3}\right)^{2}}}}
$$

Dimana:

ETr : Evapotranspirasi nyata (mm/tahun)

$\mathrm{P}$ : Curah hujan rata-rata (mm/tahun)

$\mathrm{T} \quad$ : Temperatur/ suhu $\left({ }^{\circ} \mathrm{C}\right)$

Nilai runoff atau limpasan permukaan dapat diketahui dengan perhitungan rumus (Sharma, dalam Hendrayana, 2011) sebagai berikut:

$$
\operatorname{Ro} \frac{1,511 \times p^{1,44}}{T^{1,34} \times A^{0,0613}}
$$

Dimana:

$\begin{array}{ll}\text { Ro } & \text { : Runoff }(\mathrm{cm} / \text { tahun }) \\ \mathrm{P} & : \text { Presipitasi /curah hujan (cm/tahun) } \\ \mathrm{T} & : \text { Temperature } / \text { suhu rata-rata tahunan } \\ & \quad\left({ }^{\circ} \mathrm{C}\right) \\ \mathrm{A} & : \text { Luas area }\left(\mathrm{km}^{2}\right)\end{array}$

Pendekatan untuk menghitung nilai suhu rata-rata tahunan diperoleh dari fungsi persamaan elevasi atau ketinggian tempat, dimana setiap kenaikan $100 \mathrm{~m}$ dpal, maka suhu akan berkurang $0,5^{\circ} \mathrm{C}$. Rumus untuk menghitung suhu rata-rata (Hendrayana, 2011), sebagai berikut: 
$\mathrm{T}$ hitung $=\mathrm{T}$ diketahui-(elevasi $\mathrm{T}$ $\begin{array}{llllll}\text { diketahui-elvasi } \mathrm{T} \text { hitung)/ } & 100) & \mathrm{x} & 0,5 & \left.{ }^{\circ} \mathrm{C}\right)\end{array}$ (4)

Tabel 1. Nilai point faktor untuk material zona tidak jenuh / lapisan penutup / overlaying material $(\mathrm{La})$

\begin{tabular}{|c|c|c|}
\hline $\begin{array}{c}\text { Kelas Tekstur } \\
\text { Batuan }\end{array}$ & $\begin{array}{c}\text { Kode Tekstur } \\
\text { Batuan (AG } \\
\text { Boden, 1996) }\end{array}$ & $\begin{array}{l}\text { Nilai } \\
\text { Faktor }\end{array}$ \\
\hline $\begin{array}{l}\text { Pasir dengan } \\
\text { kerikil-kerikil } \\
\text { pasiran }\end{array}$ & Gs,SG & 8 \\
\hline Pasir sedang & $\mathrm{mS}, \mathrm{mSgs}$ & 11 \\
\hline $\begin{array}{l}\text { Pasir sedang-halus, } \\
\text { pasir halus-sedang, } \\
\text { pasir kasar-halus, } \\
\text { pasirdengan sedikit } \\
\text { lanau }\end{array}$ & mSfs, fSms, Su' & 16 \\
\hline $\begin{array}{l}\text { Pasir dengan tanah } \\
\text { liat, pasirdengan } \\
\text { sedikit lempung, } \\
\text { pasir halus }\end{array}$ & $\mathrm{Sl}, \mathrm{St}$,'fs & 24 \\
\hline $\begin{array}{l}\text { Pasir lanauan, pasir } \\
\text { lempungan,lanau } \\
\text { pasiran }\end{array}$ & $\mathrm{Su}, \mathrm{St}, \mathrm{Us}$ & 29 \\
\hline $\begin{array}{l}\text { Tanah liat pasiran, } \\
\text { pasir } \\
\text { lanauandengan } \\
\text { tanah liat, lanau } \\
\text { pasiran dengan } \\
\text { tanah liat }\end{array}$ & Ls,Slu,Uls & 32 \\
\hline $\begin{array}{l}\text { Tanah liat lanauan, } \\
\text { lanau, lanau } \\
\text { lempungan }\end{array}$ & $\mathrm{Lu}, \mathrm{Uu}, \mathrm{Ut}$ & 36 \\
\hline $\begin{array}{l}\text { Tanah liat } \\
\text { lempungan, tanah } \\
\text { liat pasiran } \\
\text { lempungan }\end{array}$ & Lt,Lts & 42 \\
\hline Lempung lanauan & $\mathrm{Tu}$ & 49 \\
\hline $\begin{array}{l}\text { Lempung dengan } \\
\text { tanah liat }\end{array}$ & $\mathrm{Tl}$ & 51 \\
\hline Lempung & $\mathrm{Tt}$ & 56 \\
\hline
\end{tabular}

Sumber : Hendrayana dan Putra, 2008; Hendrayana, 2011

Tabel 2. Nilai point faktor untuk ketebalan zona tidak jenuh / kedalaman muka airtanah (Z)

\begin{tabular}{cc}
\hline Kedalaman airtanah $(\mathrm{m})$ & Nilai Faktor \\
\hline 1,0 & 1,0 \\
1,5 & 1,5 \\
2,0 & 2,0
\end{tabular}

\begin{tabular}{rr}
2,5 & 2,5 \\
3,0 & 3,0 \\
3,5 & 3,5 \\
4,0 & 4,0 \\
dst & dst \\
\hline
\end{tabular}

Sumber :Hendrayana dan Putra, 2008; Hendrayana, 2011

Tabel 3. Nilai point faktor untuk imbuhan airtanah I recharge/ perkoalsi (Wu)

\begin{tabular}{cc}
\hline $\begin{array}{c}\text { Recharge rata-rata } \\
\text { (mm/tahun) }\end{array}$ & Nilai Faktor \\
\hline$<50$ & 14 \\
$50-100$ & 10 \\
$100-200$ & 8 \\
$200-300$ & 6 \\
$300-400$ & 5 \\
$400-500$ & 4 \\
$500-600$ & 3 \\
$>600$ & 2 \\
\hline
\end{tabular}

Sumber : Hendrayana dan Putra, 2008; Hendrayana, 2011

Untuk mendapatkan nilai distribusi indek penilaian kelas parameter kerentanan airtanah dihitung dengan kombinasi linier ketiga parameter tersebut dengan pendekatan rumus (Putra, 2007 dalam Hendrayana dan Putra, 2008; Hendrayana, 2011), sebagai berikut:

$\operatorname{SVV}\left(\mathrm{P}_{\mathrm{T}}\right)=\mathrm{La}+\mathrm{Z}+\mathrm{Wu}$

Dimana:

PT : Nilai akhir dari keefektifan perlindungan dari zona tak jenuh air

La : Nilai rata-rata dari batuan penutup $\mathrm{La}=\left(\mathrm{L}_{1}+\mathrm{L}_{2}+\ldots+\right.$ $\left.\mathrm{L}_{\mathrm{n}}\right) / \mathrm{n}$

Z :Nilai ketebalan zona tak jenuh air

$\mathrm{Wu} \quad$ :Nilai dari recharge rata-rata

n : Jumlah lapisan batuan penutup akuifer (Gambar 2)

Untuk mendapatkan nilai total indek Simple Vertical Vulnerability (SVV), penentuan nilai setiap kelas dijumlahkan dengan fungsi korelasi linier ketiga parameter yang dihitung menggunkan perangkat lunak Sistem Informasi Geografis (SIG) untuk mengambarkan distribusi 
keruangan (spasial) dengan fungsi overlay (tumpeng susun) penjumlahan nilai spasial analysis. Langkah kerja penilaian dan perhitungan indek kerentanan dengan metode Simple Vertical Vulnerability (SVV) disajikan pada Gambar 1. Nilai kelas kerentanan metode Simple Vertical Vulnerability (SVV) mengacu lima (5) indek kelas, dengan pembagian kelas didasarkan pada (Putra, 2007 dalam Hendrayana dan Putra, 2011), seperti yang disajikan pada Tabel 4 sebagai berikut :

Tabel 4. Kelas Penilaian Indek Simple Vertical Vulnerability (SVV) dan klasifikasi kerentanan airtanahnya

\begin{tabular}{|c|c|c|c|}
\hline $\begin{array}{c}\text { Rentang } \\
\text { peniliaan } \\
\text { akhir }\end{array}$ & $\begin{array}{c}\text { Keefektifan } \\
\text { perlindungan } \\
\text { dari lapisan } \\
\text { penutup } \\
\text { akuifer }\end{array}$ & $\begin{array}{c}\text { Kerentanan } \\
\text { air tanah } \\
\text { intrinsik }\end{array}$ & $\begin{array}{c}\text { Waktu } \\
\text { tempuh } \\
\text { relatif di } \\
\text { dalam } \\
\text { zona } \\
\text { tidak } \\
\text { jenuh air }\end{array}$ \\
\hline$>70$ & $\begin{array}{l}\text { Sangat } \\
\text { Tinggi }\end{array}$ & $\begin{array}{l}\text { Sangat } \\
\text { Rendah }\end{array}$ & $>25$ \\
\hline$>65-70$ & Tinggi & Rendah & $10-25$ \\
\hline$>35-65$ & Sedang & Sedang & $3-10$ \\
\hline$>24-35$ & Rendah & Tinggi & $\begin{array}{l}\text { Beberapa } \\
\text { bulan -3 } \\
\text { tahun }\end{array}$ \\
\hline$\leq 24$ & $\begin{array}{l}\text { Sangat } \\
\text { Rendah }\end{array}$ & $\begin{array}{l}\text { Sangat } \\
\text { Tinggi }\end{array}$ & $\begin{array}{l}\text { Beberapa } \\
\text { hari - } 1 \\
\text { tahun }\end{array}$ \\
\hline
\end{tabular}

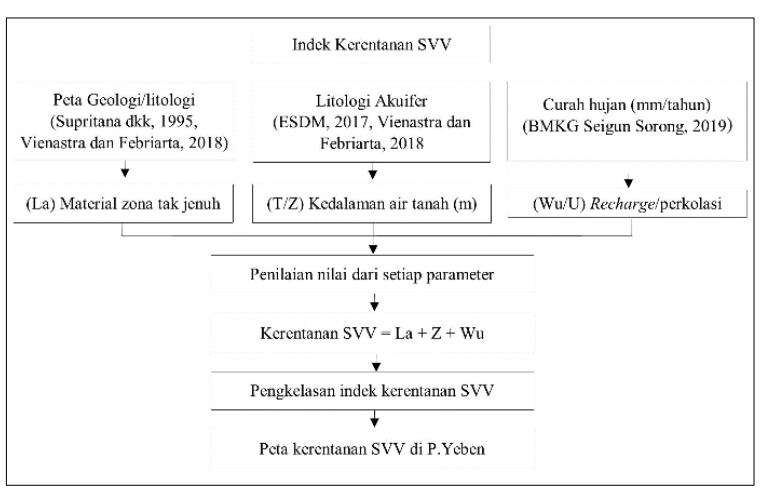

Gambar 3. Kerangka kerja perhitungan kerentanan airtanah

\section{HASIL DAN PEMBAHASAN \\ Material Zona Tidak Jenuh (La)}

Penentuan nilai material zona tidak jenuh (La) diperoleh dari pengeboran sampel oleh Vienastra dan Febriarta (2018). Berdasarkan kajian tersebut diketahui bahwa didaerah kajian, penyusun batuan pada dataran pantai tersusun oleh material pasir dengan ukuran sedang hingga kasar. Hasil penentuan nilai material zona tidak jenuh disajikan pada Tabel 5 dan distribusi tekstur batuan disajikan pada Gambar 4.

Tabel 5. Nilai Material Zona Tidak Jenuh (La)

\begin{tabular}{lr}
\hline \multicolumn{1}{c}{ Kelas Tekstur Batuan } & Nilai \\
\hline Pasir dengan kerikil-kerikil pasiran & 8 \\
Pasir sedang & 11 \\
Pasir sedang-halus, pasir halus- sedang, & 16 \\
Pasir dengan tanah liat & 24 \\
Pasir lanauan, pasir lempungan, lanau & \\
pasiran & 29 \\
Tanah liat pasiran & 32 \\
Tanah liat lempungan, tanah liat pasiran & \\
lempungan & 42 \\
\hline Sumber: ESDM (2017), Vienastra dan Febriarta \\
(2018), analisis (2020)
\end{tabular}

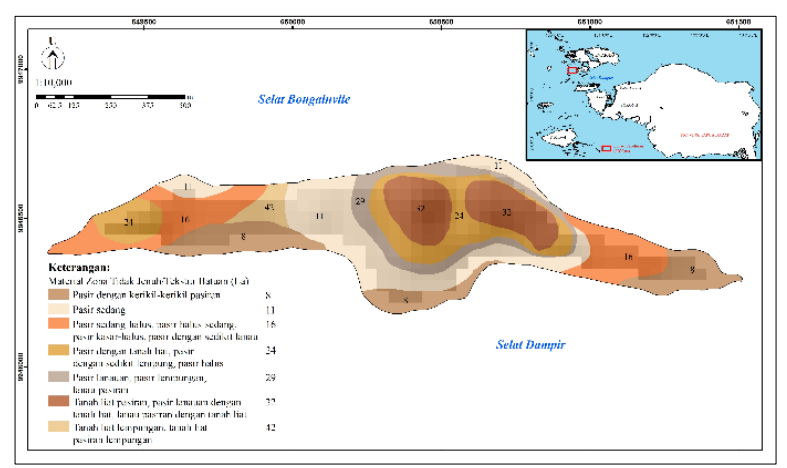

Gambar 4. Sebaran nilai tektur batuan / material zona tidak jenuh ( $\mathrm{La}$ )

\section{Ketebalan Zona Tidak Jenuh / Kedalaman Muka Airtanah (Z)}

Hasil pengukuran yang dilakukan oleh Vienastra dan Febriarta (2018) dengan pengeboran sampel bor di lokasi kajian, menunjukkan kedalaman airtanah pada dataran pantai pada bagian utara menunjukkan kedalaman 0,3 hingga $1 \mathrm{~m}$. Kedalaman airtanah pada dataran pantai pada bagian selatan menunjukkan kealaman 0,3-0,5 m. 
Bagian tengah pulau yang merupakan morfologi perbukitan batupasir kedalaman airtanah hingga $5 \mathrm{~m}$. Berdasarkan sifat litologi akuifer diketahui dilokasi kajian merupakan akuifer bebas berupa pasiran dan celah (Vienastra dan Febriarta, 2018). Hasil penentuan nilai kedalaman muka airtanah disajikan pada (Tabel 6) dan distribusi kedalaman airtanah disajikan pada (Gambar 5).

Tabel 6. Ketebalan Zona Tidak Jenuh / Kedalaman Muka Airtanah (Z)

\begin{tabular}{cc}
\hline Kedalaman Airtanah $(\mathrm{m})$ & Nilai Faktor \\
\hline 0,3 & 0,3 \\
0,5 & 0,5 \\
1 & 1 \\
2 & 2 \\
2,5 & 2,5 \\
5 & 5
\end{tabular}

Sumber: Vienastra dan Febriarta (2018), analisis (2020)

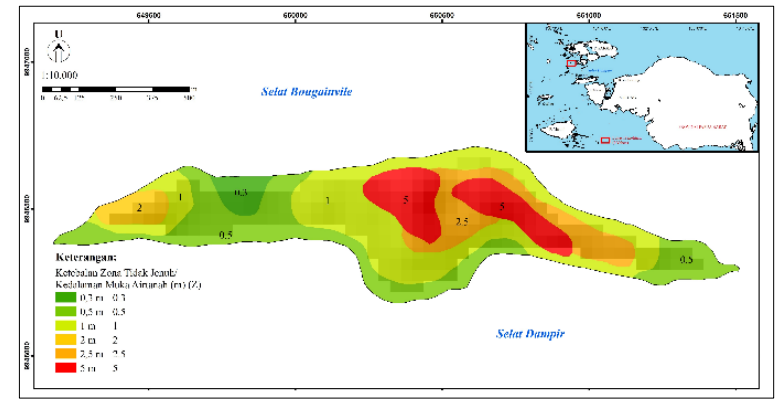

Gambar 5. Ketebalan Zona Tidak Jenuh / Kedalaman Muka Airtanah (Z)

\section{Imbuan Airtanah/Recharge/ Perkolasi (Wu)}

Daerah kajian (Pulau Yeben, Kabupaten Raja Ampat, Papua Barat) masuk kedalam hujan wilayah dengan nilai relatif sama yaitu sebesar $2.800 \mathrm{~mm} /$ tahun (BMKG, 2019). Sehingga untuk mengetahui nilai perkolasi menggunakan perhitungan curah hujan rata yaitu 2.880 $\mathrm{mm} /$ tahun.

Nilai evapotranspirasi nyata diketahui dari perhitungan rumus (2) ETr adalah $1 \mathrm{~mm} / \mathrm{tahun}$, dan nilai aliran permukaan atau runoff dari perhitungan rumus (3) Ro adalah $1.404 \mathrm{~mm} /$ tahun. Sehingga hasil nilai imbuhan airtanah/ rechargel perkolasi sebesar $1.474,89 \mathrm{~mm} /$
tahun.Nilai tersebut termasuk kedalam nilai faktor $>6$ yaitu 2. Hasil penentuan nilai imbuhan airtanah atau perkolasi disajikan pada Gambar 6 .

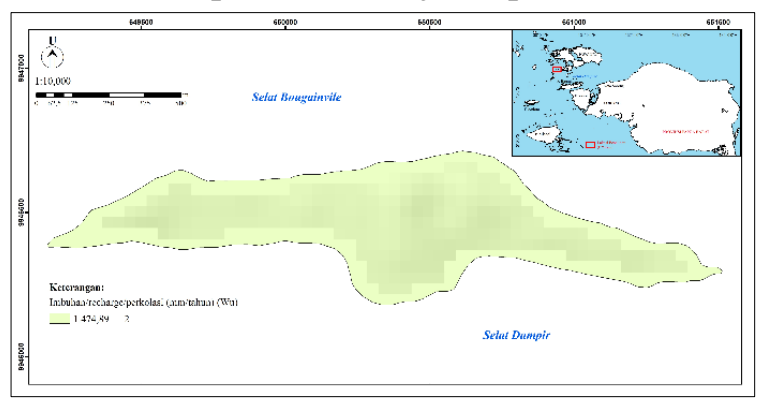

Gambar 6. Imbuan Airtanah/ Recharge/ Perkolasi (Wu)

Hasil perhitungan nilai total indek kerentanan airtanah adalah $11-44,5$ poin. Nilai tersebut dalam kelas kerentanan airtanah intrinsik kedalam kelas sedang, tinggi dan sangat tinggi. Kerentanan intrinsik menekankan pada parameter fisik geologi, diantaranya ketebalan batuan, besar rongga antar butir dan kemampuan melolosakan airtanah atau lebih dipengaruhi oleh kapasitas cekungan airtanah. Berdasarkan hasil kajian diketahui kerentanan terhadap pencemaran sangat tinggi memiliki luas $334.962,74 \mathrm{~m}^{2}$ atau $0,33 \mathrm{~km}^{2}$ $(58,5 \%)$, kerentanan tinggi memiliki luas $137.180,16 \mathrm{~m}^{2}$ atau $0,13 \mathrm{~km}^{2}(23,9 \%)$ dan kerentan sedang dengan luas $100.223,91 \mathrm{~m}^{2}$ atau $0,1 \mathrm{~km}^{2}(17,5 \%)$. Kerentanan tinggi terdistribusi mengelilingi pulau pada morfologi dataran pantai.

Hasil tersebut dipengaruhi oleh material intrisik dari tektur batuan dengan sifat media celah, yang dimungkinkan kemampuan kelulusan airtanah sangat tinggi. Sehingga nilai tersebut mempengaruhi percepatan pencemaran sumber pencemar masuk ke akuifer dangkal. Bagian tengah pada morfologi perbukitan memilki kerentanan sedang. Hasil nilai indek kerentanan sedang merupakan nilai terkecil dari total indek kerentanan. Kerentanan sedang dimungkinkan karena tektur batuan banyak ditemukan sisipan lanau dan lempung, dimana sifat tersebut lambat dalam meloloskan airtanah. Distribusi kerentanan airtanah dapat dilihat pada Gambar 7 . 


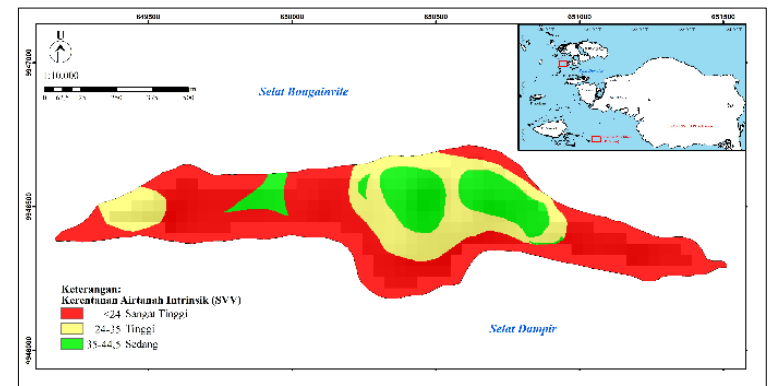

Gambar 7. Kelas Kerentanan Airtanah Intrinsik

Berdasarkan klasifikasi kerentanan airtanah secara intrinsik atau faktor fisik batuan, jika dilihat dari nilai keefektifan pada zona kerentanan intrinsik sangat tinggi, diketahui lapisan batuan pada zona tersebut (Gambar 7) memiliki tingkat keefektifan perlindungan dari lapisan penutup akuifer yang sangat rendah (Gambar 8). Nilai sangat rendah merupakan faktor intrinsik dimana tektur batuan tidak dapat menjaga atau melindungi terhadap potensi sumber pencemar masuk kedalam sistem akuifer airtanah. Kefektifan dengan kelas rendah berkorelasi dengan nilai kerentanan intrisik tinggi dan kelas nilai keefektifan lapisan penutup akuifer sangat rendah berkorelasi dengan kelas kerentanan intrinsik sedang. Berdasarkan hasil kajian dapat disipulkan bahwa jika material penyusun batuan semakin porus maka memiliki potensi kerentanan tinggi dan kemampuan batuan untuk tidak tercemar kefektifannya kelas sedang. Sebaliknya jika nilai kerentanan airtanah sedang atau rendah, potensi kemampuan batuan tidak menyebarkan pencemaran juga kecil atau percepatannya rendah. Hal tersebut dimungkinkan oleh tekstur batuan yang semakin rapat, sehingga ukuran antar hutir halus hingga sedang yang mengakibakan percepatan kelulusan air tanah kecil atau bersifat setempat.

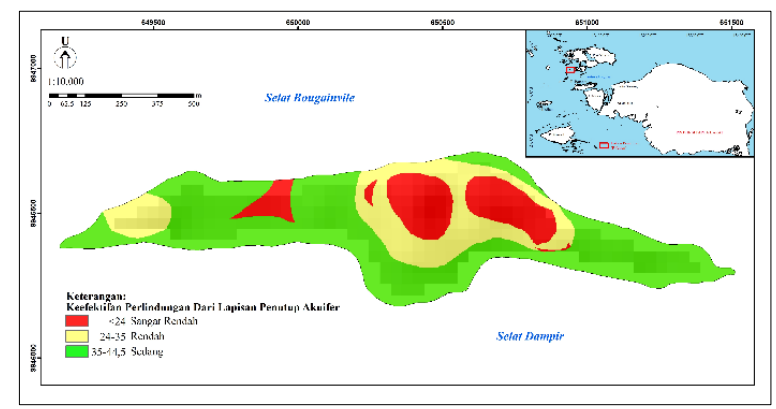

Gambar 8. Keefektifan Perlindungan dari Lapisan Penutup Akuifer

Berdasarkan distribusi kerentanan airtanah dangkal, zona atau kawasan yang potensial digunakan untuk penggunaan airtanah pada zona dengan nilai indek kerentanan 24-35 point, dimana kelas tersebut masuk kelas tinggi. Pengambilan aman atau zona pemanfaatan airtanah pada zona tersebut dapat mengacu (Permen ESDM No. 31 Tahun 2018 (Republik Indonesia, 2018), yaitu pengambilan airtanah atau pemompaan tidak lebih dari $<40 \%$ kondisi freatik airtanah. Pada zona tersebut diketahui ketebalan akuifer $2 \mathrm{~m}$ (Vienastra dan Febriarta, 2018), sehingga pengambilan aman tidak lebih hingga penurunan airtanah pada $0,8 \mathrm{~m}$ atau pada ketinggian muka freatik airtanah $1,2 \mathrm{~m}$.

Pengambilan lebih dari batas aman akan memicu terjadinya intrusi air laut masuk kedalam air tanah sehingga, kualitas fisik akan berkurang atau bahkan tidak dapat dikonsumsi. Untuk menjaga keberlangsungan airtanah dapat ditetapkan pada zona kerawanan sedang pada moroflogi perbukitan dijadikan zona tidak terbangun atau zona konservasi airtanah sebagai zona atau kawasan imbuhan airtanah setempat.

\section{KESIMPULAN}

Hasil kajian diketahui bahwa tersusun atas akuifer bebas. Jenis material penysusun litologi akuifer adalah pasiran dengan rongga antar butir sedang hingga kasar dan celah. Berdasakan penilaian nilai indek kerentanan terdapat tiga (3) kelas, yaitu sangat tinggi $(58,5 \%)$, kerentanan tinggi $(23,9 \%)$ dan kerentanan sedang $(17,5 \%)$. Zona pemanfaatan aitanah aman di Pulau Yeben berada pada zona kerentanan intrinsik tinggi dengan nilai indek 2435 poin, dengan syarat aman pemanfaatan atau pemompaan tidak lebih dari $<40 \%$ tinggi muka air freatik atau tidak lebih dari penurunan tinggi muka airtanah $0,8 \mathrm{~m}$. Pemanfaatan atau pemompaan berlebihan pada zona tersebut dapat mengakibatkan intrusi airlaut. 


\section{UCAPAN TERIMA KASIH}

Ucapan terimakasih disampaikan kepada warga Maggarai yang telah membantu dalam kegiatan survei.

\section{DAFTAR PUSTAKA}

Abuduwaili, J., Issanova, G., Saparov G. (2019). Water Resources Development and management. Springer. Springer Nature Singapore.

AG Boden. (1996). Bodenkundliche Kartieranleting, 4.- Auflage, Hannover.

Badan Standadisasi Nasional (BSN). (2005). Standar Nasional Indonesia (SNI) 13-71212005 Penyelidikan Potensi Air Tanah Skala 1:200.000 Atau Lebih Besar.Badan Standadisasi Nasional.

Badan Meteorologi Klimatologi Dan Geofisika (BMKG). (2019). Buletin Meteorologi Edisi Februari 2019. Badan Meteorologi Klimatologi Dan Geofisika Stasium Meteorologi Kelas 1 Seigun Sorong: Sorong.

Cahyadi, A. (2019). Analsisi Kerentanan Airtanah terhadap pencemaran di Pulau Koral Sangat Kecil dengan Menggunakan Metode GOD.Jurnal Geografi.16(1).48-53.

Devianto, L.A., Lusiana, N., Ramdani, F. (2019). Analisis kerentanan pencemaran air tanah di kota Batu menggunakan analisis multikriteria spasial dengan indek DRASTIC. Jurnal Wilayah dan Lingkungan. 7(2). 90104.dx.doi.org/10.14710/jwl.7.2.90-104.

Menteri Energi dan Sumber Daya Mineral (ESDM). (2017). Litologi Akuifer. 31 Mei 2017. Diakses pada 5 Mei 2020. https://geoportal.esdm.go.id/geologi.

Febriarta, E., Prabawa, B. A.,dan Rosaji, F.S.C. (2018). Sumber Daya Air di Pulau Pelapis Kepuluan karimata, Kabupaten Kayong Utara, Kalimantan Barat. Prosiding Seminar nasional Ke-4 Pengelolaan Pesisir dan Daerah Aliran Sungai. 4. 181-186. doi 10.17605/osf.io/v6nx8.

Febriarta, E., Oktama, R., Purnama, S. (2020) Analisi Daya Dukung Lingkungan Berbasis Jasa Ekosistem Penyedia Pangan dan AIr Bersih di Kabupaten Semarang. Geomedia.18(1).12-24.
Fetter, C.W. (1999). Contaminant Hydrogeology ${ }^{\text {2nd }}$ edition. Prentice Hall. Upper Saddle River. New York.

Fetter, C.W. (2010). Applied Hydrogeology Fourth Edition. Pearson New International Education: England.

Maria, R. (2017). Comparative Studies of Groundwater Vulnerability Assessment. Earth and Environmental Science.118:1-6.

Republik Indonesia. (2018). Peraturan Menteri ESDM No. 31/2018 tentang Pedoman Penetapan Zona Konservasi Air Tanah. Jakarta.

Purnama, S., Tivianton, T.A., Cahyadi, A., Febriata, E. (2019). Kajian Daerah Imbuhan Airtanah di Kabupaten Ngawi. Jurnal Geografi.16(1).54-59.

Putranto, T.T., Ali, R.K.,dan Putro, A.B. (2019). Studi Kerentanan Airtanah terhadap Pencemaran dengan Menggunakan Metode DRASTIC pada Cekungan Airtanah (CAT) Karanganyar-Boyolali, Provinsi Jawa Tengah. Jurnal Ilmu Lingkungan, 17(1), 158171, doi:10.14710/jil.17.1.158-171

Singhal, B.B.S. and Gupta, R.P. (2010). Applied Hydogeology of Fracture Rock. Springer Dordrecht Heidelberg London.: Springer.

Supriatna, S., Hakim, A.S., dan Apandi, T. (1995). Peta Geologi Lembar Waigeo, Irian Jaya.Badan Geologi, PusatPenelitian dan Pengembangan Geologi.Bandung: Badan Geologi.

Todd, D.K. and Mays, L.W. (2005). Groundwater Hydrology 3rd Edition. Denver: John Wiley $\&$ Sons. Inc.

Hendrayanan, H., dan Putra, D. (2008). Pengendalian Airtanah Sebuah Pemikiran.Jurusan Teknik Geologi Fakultas Teknik Universitas Gadjah mada. Dikases pada tanggal 4 Juni 2020.https://www.researchgate.net/publicatio $\mathrm{n} / 275964869$.

Hendrayana, Heru. (2011). Pengantar Kerentanan Airtanah Terhadap Pencemaran Dan Pemompaan Air Tanah. Jurusan Teknik Geologi Fakultas Teknik Universitas Gadjah mada. Dikases pada tanggal 4 Juni 2020.https://www.researchgate.net/publicatio $\mathrm{n} / 280035296$. 
Vienastra, S., dan Febriarta, E. (2018).

karakteristik Airtanah di Pulau Yeben

Kabupaten Raja Ampat, Papua Barat.

Prosiding Pertemuan Ilmiah Tahunan Ke-3

Perhimpunan Ahli Airtanah Indonesia

(PAAI).108-

113.https://www.researchgate.net/publication/

337274051 